\title{
PENGARUH PSIKOEDUKASI KELUARGA TERHADAP KEMAMPUAN KELUARGA DALAM MERAWAT ANGGOTA KELUARGA DENGAN SKIZOFRENIA DI KOTA SORONG
}

\author{
Butet Agustarika ${ }^{1}$ I Made Raka ${ }^{2}$ \\ ${ }^{1,2}$ Dosen Jurusan Keperawatan Poltekkes Kemenkes \\ Sorong Email : agustarika.sorong@gmail.com
}

\begin{abstract}
:
Law Number 36 of 2009 concerning Health Article 144 paragraph (1) states that health efforts are supported to ensure that everyone can enjoy a healthy psychological life, free from freedom, pressure, and other changes that can be made mental health. The prevalence of mental emotional disorders in family members over the age of 15 years 140 per 1000 in West Papua Province is 13.2\% (1995 SKRT). While the prevalence of Emotional Mental Disorders in Sorong is 7.1\% (Basic Health Research, 2008). The increasing prevalence of mental disorders in the world, in Indonesia even in the Sorong Raya region cannot be dammed along with the challenges that occur in society in the era of globalization and multi-dimensional improvement efforts. The purpose of this study was to study the Effects of Family Psychoeducation on Family Capability in Caring for Family Members with Schizophrenia in Sorong City and Regency in 2016. With the benefits of this research study, it can help and enrich research on the field of work of caring for family members who experience schizophrenia. The research design used in this study was "Quasi experimental pre-post test with the control group" with Family Psychoeducation intervention. The number of samples in this study was the total population, namely all patients who experienced disorders such as the intervention group, namely 32 respondents. The analysis used was the Mann Whitney U Test. The results showed there was an increase that helped between families caring for family members who improve schizophrenia before getting Family Psychoeducation therapy and after getting Family Psychoeducation therapy in the City and Sorong Regency ( $\mathrm{p}$ value 0.000 , which is less than 0.005 )
\end{abstract}

Keywords: Family Psychoeducation Therapy, Schizophrenia

\begin{abstract}
Abstrak :
Prevalensi gangguan mental emosional pada anggota keluarga di atas usia 15 tahun 140 per 1000 di Provinsi Papua Barat sebesar 13,2\% (SKRT 1995). Sedangkan prevalensi Gangguan Mental Emosional di Sorong sebesar 7,1\% ( Riset Kesehatan Dasar, 2008). Meningkatnya prevalensi gangguan jiwa di dunia, di Indonesia bahkan di Wilayah SorongRaya tidak dapat dibendung seiring dengan meningkatnya tuntutan hidup di masyarakat dalam era globalisasi dan terjadinya krisis multi dimensi. Tujuan penelitian ini adalah Untuk mengetahui Pengaruh Psikoedukasi keluarga Terhadap Kemampuan Keluarga dalam Merawat Anggota Keluarga dengan Skizofrenia di Kota dan Kabupaten Sorong tahun 2016.Desain penelitian yang digunakan dalam penelitian ini adalah "Quasi experimental pre-post test with control group" dengan intervensi Psikoedukasi Keluarga. Jumlah sampel dalam penelitian ini adalah total populasi yaitu seluruh pasien yang mengalami gangguan jiwa sebagai kelompok intervensi, yaitu 32 responden. Analisis yang digunakan adalah Mann Whitney U Test. Hasil penelitian menunjukkan bahwa Ada peningkatan yang bermakna antara kemampuan keluarga merawat anggota keluarganya yang mengalami Schizofrenia sebelum mendapatkan terapi Psikoedukasi Keluargadan setelah mendapatkan terapi Psikoedukasi Keluarga di Kota dan Kabupaten Sorong (p value 0,000, yaitu kurang dari 0,005)
\end{abstract}

Kata Kunci: Terapi Psikoedukasi keluarga, Skizofreni 


\section{PENDAHULUAN}

WHO, 2010 menyebutkan bahwa ada 2 komponen penting yang menjadi satu kesatuan dalam mendefinisikan arti sehat, yaitu sehat jasmani yang menekankan pada fungsi fisiologis dan sehat mental yang lebih menekankan pada keadaan mental yang stabil tanpa adanya tekanan yang berlebihan.

Undang Undang Nomor: 36 tahun 2009 tentang Kesehatan Pasal 144 ayat (1) menyatakan bahwa Upaya kesehatan jiwa ditujukan untuk menjamin setiap orang dapat menikmati kehidupan kejiwaan yang sehat, bebas dari ketakutan, tekanan, dan gangguan lain yang dapat mengganggu kesehatan jiwa. (2) Upaya kesehatan jiwa sebagaimana dimaksud pada ayat

(1) terdiri atas preventif, promotif, kuratif, rehabilitatif pasien gangguan jiwa dan masalah psikososial.

Data WHO tahun 2003 tentang masalah kesehatan jiwa di dunia 1 dari 4 keluarga sedikitnya mempunyai seorang anggota keluarga dengan gangguan kesehatan jiwa. Di Indonesia, 1 orang/keluarga mengalami masalah kesehatan jiwa, (Bahar, 1995). Laporan WHO menyebutkan satu dari empat orang bakal menderita gangguan mental atau neurologis pada satu saat dalam kehidupannya. (Kompas, 12 Oktober 1999). Hasil Survei Kesehatan Mental Rumah Tangga yang dilakukan di 11 kota oleh Jaringan Epidemiologi Psikiatri Indonesia tahun 1995 mendapatkan proporsi 185 per 1.000 penduduk rumah tangga dewasa memperlihatkan gejala gangguan kesehatan jiwa. Prevalensi gangguan mental emosional pada anggota keluarga di atas usia 15 tahun 140 per 1000 di Provinsi Papua Barat sebesar 13,2\% (SKRT 1995). Sedangkan prevalensi Gangguan Mental Emosional di Sorong sebesar 7,1\% ( Riset Kesehatan Dasar, 2008).

Penelitian Bank Dunia: Beban yang harus ditanggung akibat penyakit (Global Burden of Disease) yang menyebabkan hari-hari produktif yang hilang, pada tahun $1995 \mathrm{di}$

beberapa negara: 8,1 \% masalah kesehatan jiwa (Tahun 2000, 12,3\%, proyeksi Tahun 2020

$15 \%$ ), tuberkulosis 7,2\%, kanker 5,8\%, penyakit jantung $4,4 \%$, malaria $2,6 \%$.
Meningkatnya prevalensi gangguan jiwa di dunia, di Indonesia bahkan di Wilayah Sorong Raya tidak dapat dibendung seiring dengan meningkatnya tuntutan hidup di masyarakat dalam era globalisasi dan terjadinya krisis multi dimensi.

Keluarga merupakan unit paling dekat penderita Schizofrenia dan merupakan +perawat utam" bagi penderita Schizofrenia. Keluarga berperan dalam menetukan cara atau perawatan yang diperlukan penderita di rumah. Psikoedukasi keluarga merupakan tearpi psikososial yang efektif untuk mengurangi angka rawat dan mengurangi biaya pengobatan pada pasien Schizofrenia. Pada psikoedukasi keluarga terdapat kolaborasi dari klinisi dengan anggota keluarga pasien yang menderita gangguan jiwa berat. Tujuan dari program psikoedukasi adalah menambah pengetahuan tentang gangguan jiwa anggota keluarga sehingga diharapkan dapat menurunkan angka kambuh, dan meningkatkan fungsi keluarga (Stuart Laraia, 1998). Tujuan ini akan dicapai melalui serangkaian kegiatan edukasi tentang penyakit, cara mengatasi gejala dan kemampuan yang dimiliki keluarga. Dyck et al dalam Wulansih (2015) menemukan bahwa kelompok keluarga yang mendapat program psikoedukasi lebih efektif merawat gejal negatif daripada kelompok standar.

Oleh sebab itu, psikoedukasi keluarga berperan penting dalam meningkatkan kemampuan keluarga merawat anggota keluarga yang mengalami gangguan jiwa.

Upaya yang sudah dilakukan oleh perawat kesehatan jiwa di masing-masing puskesmas wilayah kerja Kota dan Kabupaten Sorong dalam membantu keluarga untuk merawat anggota keluarga yang mengalami Schizofrenia adalah melakukan kunjungan rumah sekaligus mengajarkan keluarga tentang perawatan diri klien. 
Hasil penelitian yang pernah dilakukan oleh Dini Rahmaniah tahun 2012 tentang pengaruh psikoedukasi terhadap kecemasan dan koping orang tua dalam merawat anak dengan talasemia mayor di RSU Kab Tanggerang Banten menunjukan bahwa terdapat pengaruh psikoedukasi terhadap kecemasan dan koping orang tua. Penelitian lain yang sejenis dilakukan oleh Yulita Kurniawati tentang efektifitas psikoedukasi pada orang tua dalam meningkatkan pengetahuan seksualitas remaja reterdasi mental ringan menunjukan bahwa pada kelompok eksperimen, psikoedukasi pada orang tua efektif untuk meningkatkan pengetahuan seksualitas pada remaja retardasi mental ringan.

Prevalensi gangguan mental emosional pada anggota keluarga di atas usia 15 tahun 140 per 1000 di Provinsi Papua Barat sebesar 13,2\% (SKRT 1995). Sedangkan prevalensi Gangguan Mental Emosional di Sorong sebesar 7,1\% (Riset Kesehatan Dasar, 2008). Jumlah tersebut diperkirakan akan terus meningkat seiring meningkatnya kebutuhan ekonomi serta bencana alam yang sering terjadi di wilayah Papua Barat seperti gempa bumi, banjir, tanah longsor dan lain-lain. Jumlah pasien Schizofrenia yang berobat ke 5 wilayah kerja Puskesmas di Kota dan Kabupaten Sorong sampai bulan Juni sebanyak 42 orang.

\section{METODE}

\section{Desain dan Metodologi Penelitian}

Desain penelitian yang digunakan dalam penelitian ini adalah "Quasi experimental prepost test with control group" dengan intervensi Psikoedukasi Keluarga. Desain ini digunakan untuk mempelajari fenomena dalam kerangka "korelasi sebab- akibat"dengan memberikan perlakuan atau manipulasi pada subjek penelitian, untuk kemudian dipelajari efek perlakuan tersebut (Bahtiar, 2000).

Landasan teori yang melatar belakangi pemberian Psikoedukasi Keluarga adalah teori psikoedukasi dalam merawat anggota keluarga yang mengalami Schizofrenia oleh Keliat.

\section{Populasi dan Sampel}

\author{
1. Populasi \\ Populasi adalah keseluruhan individu \\ yang menjadi acuan hasil-hasil penelitian yang
}

mempunyai karakteristik tertentu (Bahtiar, dkk., 2000).Populasi pada penelitian ini adalah seluruh pasien yang mengalami Schizofrenia di wilayah Kota dan Kabupaten Sorong tahun 2016.

2. Sampel

Jumlah Sampel dalam penelitian ini adalah 16 orang per kelompok dengan menggunakan teknik purposive sampling yaitu pemilihan sekelompok subyek didasarkan atas ciri-ciri tertentu yang dipandang mempunyai sangkut paut yang erat dengan ciri-ciri populasi yang sudah diketahui sebelumnya (Margono, 2004).

\section{Kriteria Inklusi}

a. Ayah, ibu atau saudara dari anggota keluarga sebagai care giver utama pasien yang mengalami Schizofrenia yang berdomisili di Kota dan Kabupaten Sorong

b. Keluarga mampu membaca dan menulis

c. Bersedia dijadikan responden

\section{Analisa Data}

1. Analisis Univariat Pendidikan dan pekerjaanresponden merupakan data katagorik yang dianalisis untuk menghitung frekuensi dan persentase variabel. Kemampuan keluarga merupakan data numerik yang dianalisis untuk menghitung mean, median, standar deviasi, confidence interval $95 \%$, nilai maksimal dan minimal. Penyajian data masingmasing variabel dalam bentuk tabel dan diinterpretasikan berdasarkan hasil yang diperoleh.Hasil statistik deskriptif meliputi mean, median, standar deviasi. Deskripsi univariat dilakukan pada setiap variabel yang diteliti.

2. Analisis Bivariat

Analisis bivariat dilakukan untuk membuktikan hipotesis penelitian yaitu melihat pengaruh psikoedukasi keluargaterhadap kemampuan keluarga merawat anggota keluarga yang mengalami Schizofrenia sebelum dan sesudah dilakukan psikoedukasi keluargadi wilayah Kota dan Kabupaten Sorong. Uji statistiknya menggunakan Mann Whitney $U$ Test 


\section{Skema1}

Kerangka Kerja Pengaruh Terapi Psikoedukasi Keluarga Terhadap Kemampuan Keluarga Merawat Anggota Keluarga yang Mengalami Schozofrenia.

\begin{tabular}{|c|c|c|c|}
\hline Pre test & & Intervensi & Post test \\
\hline $\begin{array}{l}\text { Pre } \\
\text { test }\end{array}$ & $\begin{array}{l}\text { Terapi } \\
\text { Psikoedukasi } \\
\text { Keluarga klien } \\
\text { dilakukan } \\
\text { sebanyak } 2 \\
\text { sesi dengan } 2 \\
\text { kali pertemuan }\end{array}$ & $\begin{array}{l}\text { Sesi I : Identifikasi kemampuan } \\
\text { keluarga merawat dan } \\
\text { mengajarkan cara merawatanggota } \\
\text { keluarga dgn Schizofrenia }\end{array}$ & $\begin{array}{l}\text { Post test } \\
\text { setelah selesai } \\
\text { terapiPsikoed } \\
\text { ukasi } \\
\text { Keluarga }\end{array}$ \\
\hline $\begin{array}{l}\text { Pre } \\
\text { test }\end{array}$ & & Kelompok Kontrol & Post test \\
\hline
\end{tabular}

\section{HASIL PENELITIAN}

Tabel 1.Distribusi responden berdasarkan jenis kelamin, umur, pendidikan dan pekerjaan pada Kelompok Intervensi dan Kelompok Kontrol di Wilayah Puskesmas Kota \& KabupatenSorong $(\mathrm{n}=32)$

\begin{tabular}{|c|c|c|c|c|c|c|}
\hline \multirow[t]{2}{*}{ Karakteristik } & \multicolumn{2}{|c|}{$\begin{array}{c}\text { Kelompok } \\
\text { intervensi } \\
(\mathbf{n}=16)\end{array}$} & \multicolumn{2}{|c|}{$\begin{array}{c}\text { Kelompok } \\
\text { kontrol } \\
(\mathrm{n}=16)\end{array}$} & \multicolumn{2}{|c|}{$\begin{array}{l}\text { Jumlah } \\
(\mathbf{n}=86)\end{array}$} \\
\hline & $\mathbf{N}$ & $\%$ & $\mathbf{n}$ & $\%$ & $\mathbf{n}$ & $\%$ \\
\hline \multicolumn{7}{|l|}{ 1. Jenis kelamin } \\
\hline a. Laki-laki & 4 & 25 & 3 & 18,8 & 7 & 21,9 \\
\hline b. Perempuan & 12 & 75 & 13 & 81,2 & 25 & 78,1 \\
\hline TOTAL & 16 & 100 & 16 & 100 & 32 & 100 \\
\hline \multicolumn{7}{|l|}{ 2. Umur } \\
\hline a. Dewasa Awal & 1 & 6,2 & 0 & 0 & 1 & 3,1 \\
\hline b. Dewasa Akhir & 4 & 25 & 1 & 6,2 & 5 & 15,6 \\
\hline c. Lansia & 11 & 68,8 & 15 & 93,8 & 26 & 81,2 \\
\hline TOTAL & 16 & 100 & 16 & 100 & 32 & 100 \\
\hline \multicolumn{7}{|l|}{ 3. Pendidikan } \\
\hline a. Pendidikan Dasar & 0 & 0 & 1 & 6,2 & 1 & 3,1 \\
\hline b. Pendidikan SMP & 4 & 25,0 & 3 & 18,8 & 7 & 21,9 \\
\hline c. Pendidikan SMA & 11 & 68,8 & 12 & 75,0 & 23 & 71,9 \\
\hline d. Perguruan Tinggi & 1 & 6,2 & 0 & 0 & 1 & 3,1 \\
\hline TOTAL & 16 & 100 & 16 & 100 & 32 & 100 \\
\hline
\end{tabular}




\begin{tabular}{lcccccc}
\hline a. Bekerja & 8 & 50 & 7 & 46,7 & 15 & 46,9 \\
b. Tidak bekerja & 8 & 50 & 9 & 52,9 & 17 & 53,1 \\
TOTAL & $\mathbf{1 6}$ & $\mathbf{1 0 0}$ & $\mathbf{1 6}$ & $\mathbf{1 0 0}$ & $\mathbf{3 2}$ & $\mathbf{1 0 0}$ \\
\hline
\end{tabular}

Hasil analisis tabel 1 dari responden yang berjumlah 32 orang sebagian besar berjenis kelamin perempuan sebanyak $25(78,1 \%)$, termasuk golongan umur lanjut usia sebanyak 26 (81,2\%), sebagian besar mempunyai tingkat pendidikan SMTA yaitu sebanyak 23 (71,9\%), sebagian besar responden tidak bekerja sebanyak 17 orang $(53,1 \%)$.

Tabel 2.Distribusi Frekuensi Kemampuan Keluarga Merawat Anggota Keluarga yang mengalami Schizofrenia Sebelum dan Sesudah diberikan Terapi Psikoedukasi Keluarga pada

\begin{tabular}{|c|c|c|c|c|c|c|}
\hline \multirow[t]{2}{*}{ Kemampuan Merawat } & \multicolumn{2}{|c|}{$\begin{array}{c}\text { Kelompok } \\
\text { intervensi } \\
(\mathrm{n}=16)\end{array}$} & \multicolumn{2}{|c|}{$\begin{array}{c}\text { Kelompok } \\
\text { kontrol } \\
(\mathbf{n}=16)\end{array}$} & \multicolumn{2}{|c|}{$\begin{array}{l}\text { Jumlah } \\
(n=32)\end{array}$} \\
\hline & $\mathbf{N}$ & $\%$ & $\mathbf{n}$ & $\%$ & $\mathrm{n}$ & $\%$ \\
\hline \multicolumn{7}{|l|}{ 1. Pre } \\
\hline a. Cukup & 13 & 81,2 & 13 & 81,2 & 26 & 81,2 \\
\hline b. Baik & 3 & 18,8 & 3 & 18,8 & 6 & 18,8 \\
\hline TOTAL & 16 & 100 & 16 & 100 & 32 & 100 \\
\hline \multicolumn{7}{|l|}{ 2. Post } \\
\hline a. Cukup & 1 & 6,2 & 13 & 81,2 & 14 & 43,8 \\
\hline b. Baik & 15 & 93,8 & 3 & 18,8 & 18 & 56,2 \\
\hline TOTAL & 16 & 100 & 16 & 100 & 32 & 100 \\
\hline
\end{tabular}

Hasil analisis tabel 2 dari responden yang berjumlah 32 orang sebagian besar mempunyai kemampuan cukup sebanyak $13(81,2 \%)$ pada kelompok intervensi dan kontrol sebelum dilakukan Terapi, sebagian besar mempunyai kemampuan baik sebanyak 15 (93,8\%) pada kelompok intervensi dan sebagian besar mempunyai kemampuan cukup sebanyak 13 (81,2\%) pada kelompok kontrol setelah dilakukan Terapi. 
Tabel 3.Analisis Kemampuan Keluarga Merawat Anggota Keluarga yang Mengalami Schizofrenia Sesudah Terapi Psikoedukasi Keluarga pada Kelompok Intervensi dan Kelompok Kontrol di Kota \& Kab. Sorong Tahun 2016 $(n=32)$

Mann-Whitney Test

\begin{tabular}{|c|c|c|c|c|}
\hline \multicolumn{5}{|c|}{ Ranks } \\
\hline & $\begin{array}{l}\text { Pre_Interv } \\
\text { ensi }\end{array}$ & $\mathrm{N}$ & Mean Rank & Sum of Ranks \\
\hline \multirow[t]{3}{*}{ Post_Intervensi } & Sebelum & 16 & 9.31 & 149.00 \\
\hline & Sesudah & 16 & 23.69 & 379.00 \\
\hline & Total & 32 & & \\
\hline
\end{tabular}

Test Statistics ${ }^{b}$

\begin{tabular}{|l|r|}
\hline & \multicolumn{1}{|c|}{ Post_Intervensi } \\
\hline Mann-Whitney U & 13.000 \\
Wilcoxon W & 149.000 \\
Z & -4.358 \\
Asymp. Sig. (2-tailed) & .000 \\
Exact Sig. [2*(1-tailed Sig.)] & .000 \\
\hline
\end{tabular}

Analisis kemampuan keluarga merawat anggota keluarga yang mengalami Schizofrenia sesudah dilakukan terapi Psikoedukasi Keluarga menunjukkan bahwa kemampuan merawat pada kelompok intervensi meningkat secara bermakna dibandingkan kelompok kontrol ( $\mathrm{p}$ value < $0,05)$. 


\section{PEMBAHASAN}

1. Pengaruh Terapi Psikoedukasi Keluarga Terhadap Kemampuan keluarga dalam merawat anggota keluargannya yang mengalami Schizofrenia

a. Kemampuan keluarga sebelum terapi Psikoedukasi Keluarga

Skor kemampuan keluarga merawat anggotanya yang mengalami Schizofrenia sebelum mendapatkan terapi Psikoedukasi Keluarga sebagian besar di rentang cukup sebanyak 13 (81,2\%), baik pada kelompok intervensi maupun kelompok kontrol.

Hal ini sesuai dengan pendapat Kembaren, 2011 bahwa salah satu fungsi keluarga adalah perawatan kesehatan, yaitu berupa praktek merawat anggota keluarga, termasuk kemampuan keluarga meningkatkan dan memelihara kesehatan jiwa anggota keluarganya yang mengalami Schizofrenia. Asumsi peneliti bahwa kemampuan keluarga yang cukup sebagai care giver dapat ditingkatkan menjadi kemampuan yang baik apabila diberikan intervensi berupa Terapi Psikoedukasi..

b. Kemampuan keluarga sesudah terapi Psikoedukasi Keluarga

Skor kemampuan keluarga merawat anggotanya yang mengalami Schizofrenia sesudah mendapatkan terapi Psikoedukasi Keluarga sebagian besar berkemampuan baik sebanyak 15 (93,8\%) pada kelompok intervensi dan sebagian besar berkemampuan cukup sebanyak $13(81,2 \%)$ pada kelompok kontrol.

Teori tentang fungsi keluarga merawat anggotanya yang mengalami Schizofrenia menjelaskan bahwa peningkatan kemampuan anggota keluarga sebagai care giver di rumah pada penelitian ini dipengaruhi pelaksanaan Terapi Psikoedukasi, dimana terapis mengidentifikasi terlebih dahulu kemampuan keluarga merawat anggotanya yang mengalami Schizofrenia serta mengajarkan anggota keluarga tersebut bagaimana cara merawat kebersihan diri anggota keluarganya.

c. Pengaruh Terapi Psikoedukasi Keluarga Terhadap kemampuan keluarga merawat anggotanya yang mengalami Schizofrenia

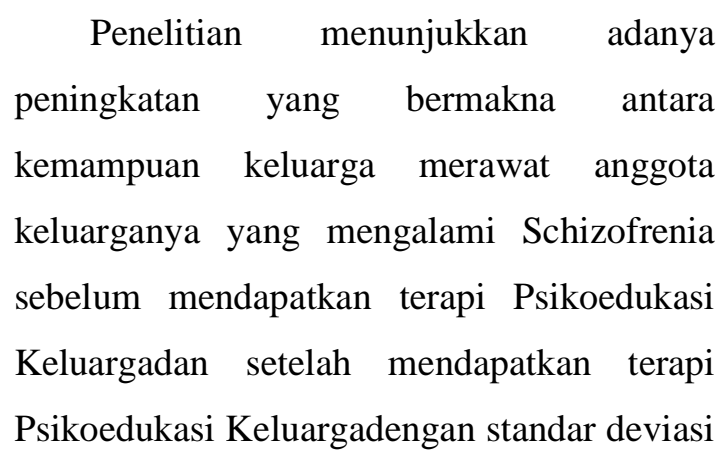
$0,250$ (p-value $=0,000$ atau $<0,05)$. Peningkatan kemampuan merawat anggota keluarga yang mengalami Schizofrenia terjadi dalam kategori yang berbeda yaitu kemampuan merawat cukup ke kemampuan merawat yang baik.

Sesi pertama pada responden yang diberikan Terapi Psikoedukasi Keluarga diberikan secara individual dan berkelompok. Bustillo (2000) menyatakan bahwa intervensi 
secara individual karena setiap care giver mempunyai permasalahan yang berbeda khususnya yang menyangkut cara merawat anggota keluarga yang mengalami gangguan jiwa atau Schizofrenia.

Pada sesi kedua anggota keluarga diberikan penjelasan tentang merawat anggota keluarganya untuk kebersihan diri, penjelasan tentang cara mengatasi apabila anggota keluarganya mengalami kekambuhan serta fasilitas kesehatan yang dapat dikunjungi untuk berobat secara rutin ataupun sewaktu-waktu bila terjadi kekambuhan.

Tujuan dari program psikoedukasi adalah menambah pengetahuan tentang gangguan jiwa anggota keluarga sehingga diharapkan dapat menurunkan angka kambuh, dan meningkatkan fungsi keluarga (Stuart Laraia, 1998). Tujuan ini akan dicapai melalui serangkaian kegiatan edukasi tentang penyakit, cara mengatasi gejala dan kemampuan yang dimiliki keluarga. Dyck et al (dalam Kembaren, 2011) menemukan bahwa kelompok keluarga yang mendapat program psikoedukasi lebih efektif merawat gejala negatif daripada kelompok standar.

Penelitian ini sejalan dengan hasil penelitian sejenis yang dilakukan oleh Sormin dan Sulastri tahun 2016 tentang Psikoedukasi Keluarga Meningkatkan Pengetahuan Mengontrol Perilaku Kekerasan Orang Dengan Gangguan Jiwa di Wilayah Kerja Puskesmas Kedaton, Bandar Lampung, yang menunjukkan bahwa pengetahuan pasien pada kelompok intervensi lebih baik dibandingkan kelompok kontrol $(\mathrm{p}=1,001)$.

\section{SIMPULAN}

Ada peningkatan yang bermakna antara kemampuan keluarga merawat anggota keluarganya yang mengalami Schizofrenia sebelum mendapatkan terapi Psikoedukasi Keluarga dan setelah mendapatkan terapi Psikoedukasi Keluarga.

\section{SARAN}

1. Bagi perawat yang sudah mendapat pelatihan tentang CMHN (Community Mental Health Nursing) diharapkan dapat memberikan terapi Psikoedukasi Keluarga kepada anggota keluarga yang mengalami Schizofrenia sebagai care giver

2. Bagi petugas kesehatan di Puskesmas pemegang program kesehatan jiwaq dianjurkan untuk meningkatkan kunjungan rumah kepada keluarga yang mempunyai pasien dengan Schizofrenia agar pelayanan kesehatan yang diberikan lebih efisien

3. Bagi peneliti selanjutnya direkomendasikan untuk melakukan penelitian dengan variable yang berbeda, seperti variabel karakteristik si terapis dan variabel hubungan care giver terhadap anggota keluarga yang mengalami Schizofrenia. 


\section{DAFTAR PUSTAKA}

Baron, R.A. dan Donn Byrne. 2003. Psikologi

Sosial. Jakarta : Erlangga.

Jhonson,C.L. 1988. Ex Familia. New Brunswick

: Rutger University Press.

Kembaren, L. 2011. Psikoedukasi Keluarga Pada Pasien Skizofrenia. Jakarta.

Lemeshow, S. Hosmer, D., Lwanga, S. (1997). Besar sampel dalam penelitian kesehatan. Yogyakarta :Gadjah Mada University Press.

Maramis, W.E. 2005. Ilmu Kedokteran Jiwa. Surabaya : Erlangga University Press.

Richard, R. Clayton. 2003. The Family, Mariage and Social Change.hal 58.

Muin, Idianto. 2013. Kelompok Peminatan IlmuIlmu Sosial. Jakarta : Erlangga, Hal.156- 172.

Psikoedukasi Keluarga Pada Pasien Schizofrenia. Available from: http://www.lahargokembaren.com/2009/11/psik oedukasi-keluarga-pada-pasien.html. Diunduh tanggal 30 Mei 2016.

Peran Keluarga dalam Penanganan Pasien Schizofrenia. Avaiable from : http://www.wulansih.com/2015/peran-keluargadalam-penanganan-pasien-schizofrenia.html. Diunduh tanggal 2 Juni 2016.

Sugeng Iwan. 2009. Pengasuhan Anak Dalam Keluarga. Avaiable from : http://www.sugengiwan.com/2009/pengasuhananak-dalam-keluarga.html. Diunduh tanggal 30 Mei 2016.

Stuart, G.W., \& Laraia, M.T. (2005). Principles and practice of psychiatric nursing. ( $8^{\text {th }}$ edition). St Louis: Mosby

Sastroasmoro,S., dan Ismael, S. (2008). Dasardasar metodologi penelitian klinis (edisi ke-3). Jakarta : CV Sagung Seto.
Sormin \& Sulastri. (2016). Psikoedukasi Keluarga Meningkatkan Pengetahuan Mengontrol Perilaku Kekerasan Orang Dengan Gangguan Jiwa di Wilayah Kerja Piskesmas Kedaton, Bandar Lampung jurnal) 